Pesq. Vet. Bras. 37(5):425-431, maio 2017 DOI: $10.1590 / \mathrm{S} 0100-736 \mathrm{X} 2017000500001$

\title{
Biochemical, thermographic, and follicular responses of murine models of hormone-treated bovine ovarian renal capsule xenografts ${ }^{1}$
}

\author{
Muriel M.L. Pimentel ${ }^{2 *}$, Fernanda A. Santos ${ }^{2}$, Ana C.G. Teixeira² ${ }^{2}$, Roberta G. Izzo ${ }^{2}$, \\ Mikael A. Lima², Michelly F. Macedo ${ }^{2}$ and Marcelo B. Bezerra ${ }^{2}$
}

\begin{abstract}
Pimentel M.M.L., Santos F.A., Teixeira A.C.G., Izzo R.G., Lima M.A., Macedo M.F. \& Bezerra M.B. 2017. Biochemical, thermographic, and follicular responses of murine models of hormone-treated bovine ovarian renal capsule xenografts. Pesquisa Veterinária Brasileira 37(5):425-431. Laboratorio de Transplante de Gónadas e de Produção de Embriões In Vitro, Universidade Federal Rural do Semi-Árido, Av. Francisco Mota 572, Costa e Silva, Mossoró, RN 59625-900, Brazil. E-mail: murielpimentel@yahoo.com.br

This study aimed to evaluate the characteristics of two different murine models of hormone-treated renal-encapsulated bovine ovarian tissue xenotransplantation. Two immunodeficient mouse models (BALB/c Nude and C57BL6 SCID) were xenografted with ovarian pieces from heifers and each group was subjected to two hormonal treatments of eCG or a combination of FSH+LH. Donor ovaries and recipients were evaluated by histology and infrared thermography at different times. At the time of xenograft collection, animals were evaluated for alterations in hepatorenal biochemistry. The statistical test used in the study was ANOVA, followed by Tukey's test. Among the strains, $80 \%$ of C57BL6 SCID and $77 \%$ of BALB/c Nude mice showed development and vascularization of the transplanted tissue, which acquired cyclicity at 19 and 9 days post-transplant, respectively. Hemorrhagic follicles in xenografts induced with FSH+LH were found in the C57BL6 SCID strain. Infrared thermography was insufficient to distinguish the tissue donor recipient. In conclusion, the C57BL6 SCID strain appears to be the best host for ovarian xenografts, since the transplants in these mice were viable and showed robust follicular development. This work will aid future choices of immunodeficient strains for xenografting procedures.
\end{abstract}

INDEX TERMS: Xenotransplantation, ovary, heifers, mice.

RESUMO.- [Respostas bioquímicas, termográficas e foliculares de modelos murinos tratados hormonalmente após xenotransplante de ovário bovino sob a cápsula renal.] Este estudo teve como objetivo avaliar as características dos dois diferentes modelos de murinas tratadas hormonalmente após xenotransplante de tecido ovariano bovino sob a cápsula renal. Dois modelos de camundongos imunodeficientes (BALB/c NUDE e C57BL6 SCID) receberam fragmentos de ovário de novilhas e cada grupo foi submetido a dois tratamentos hormonais de eCG ou uma combinação de FSH+LH. Ovários doadores e receptores foram avaliados por histologia

\footnotetext{
${ }^{1}$ Received on June 24, 2015.

Accepted for publication on August 9, 2016.

${ }^{2}$ Laboratorio de Transplante de Gônadas e de Produção de Embriões In Vitro, Universidade Federal Rural do Semi-Árido, Av. Francisco Mota 572, Bairro Costa e Silva, Mossoró, RN 59625-900, Brazil. *Corresponding author: murielpimentel@yahoo.com.br
}

e termografia infravermelha em diferentes momentos. No momento da retirada do xenotranplante, os animais foram avaliados quanto a alterações na bioquímica hepatorrenal. 0 teste estatístico utilizado no estudo foi ANOVA, seguido do teste de Tukey. Entre as linhagens, 80\% de C57BL6 SCID e $77 \%$ das BALB/c NUDE mostraram desenvolvimento e vascularização do tecido transplantado, que adquiriu a ciclicidade 19 e 9 dias após o transplante, respectivamente. Corpos hemorrágicos foram encontrados após o xenotransplante induzidos com FSH+LH na linhagem C57BL6 SCID. A termografia infravermelha foi insuficiente para distinguir o tecido doador do receptor. Em conclusão, a linhagem C57BL6 SCID demonstrou ser o melhor hospedeiro para xenotransplante de ovário, uma vez que os transplantes nestes camundongos foram viáveis e mostraram desenvolvimento folicular. Este trabalho ajudará futuras escolhas de linhagens imunodeficientes para procedimentos de xenotranplante. 
TERMOS DE INDEXAÇÃO: Xenotransplante, ovário, novilhas, camundongas.

\section{INTRODUCTION}

Ovarian xenografting is a valuable technique with applications in animal breeding for the maintenance of the activity of fresh, cooled, or cryopreserved ovaries. Gonads can survive post-mortem for several hours if they are well maintained (Wiedemann et al. 2012). Thus, ovarian xenografting allows the resumption of hormonal functions in cases of the recent death of animals with high breeding value, or ecologically or scientifically important animals. The technique can also be used for the preservation of endangered species (Kikuchi et al. 2011).

The insertion of tissues (or fragments thereof) in a non-self-recipient can be performed near or away from the original anatomical site (Sonmezer \& Oktay 2010). Although, there is no consensus in literature, the criteria for eligibility of site of transplantation varies according the expected responses, for example, the subcutaneous site is frequently chose due the easy for assessment of follicle development or oocyte retrieval. Another receptor site commonly used for xenotransplantation is the kidney capsule (Gosden et al. 1994), which is chosen due to the higher vascularity of the kidneys compared to that of other sites such as under the skin or in the ovarian pouch (Yang et al. 2006). To perform this technique, either immunosuppressive drugs (Samaniego et al. 2006) or immunodeficient animals (Aubard 2003) should be used in order to reduce the possibility of rejection of the transplanted tissue (Bedaiwy et al. 2008, Silber et al. 2010, Silber 2012, Von Schonfeldt et al. 2012).

Although there are techniques available for evaluating xenografts, such as the observation of vaginal smears and histology, biochemical and thermographic techniques are useful for providing important information related to the recipient. For example, infrared thermography consists of capturing radiation emitted by animal tissues and converting it into thermograms or thermographic images that serve as maps of surface temperature with contours that vary according to the anatomical location (Stewart et al. 2005). This approach has facilitated the diagnosis of issues during reproduction and is less invasive and more rapid than other techniques; its use has therefore been widely adopted across the field of veterinary medicine (Ricarte et al. 2014). In this context, the use of infrared thermography in transplantation is geared towards a prior assessment of the surface temperature of the donor tissue at its original location, and then subsequently after it has been xenografted into the recipient.

In addition, the knowledge of hepatorenal biochemical parameters of recipient mice is very important, as they can reflect the functional consequences of surgical interventions at the organismal level. In the case of ovarian xenografts under the kidney capsule, the assessment of circulating metabolites that are produced by the kidney and liver will provide valuable information on the overall condition of the animal. Such indices are also useful for monitoring the receptor site, thus permitting researchers to determine whether xenotransplantation actually causes injury to the recipient.
Currently, there are two different immunodeficient mice models (Nude or SCID) that can be used to evaluate xenografting; Nude mice are homozygous recessive for the autosomal gene located on chromosome 11. This characteristic induces abnormal development of the thymus in animals, leaving them so deficient in $\mathrm{T}$ lymphocytes. The absence of hair is also characteristic of this condition, hence Nude name (Shultz et al. 1995). Animals SCID (Severe Combined Imunno Deficiency) in turn, are autosomal mutant chromosome 16 which induces the formation of precursor cells of the defective lymphoid system (Johnson, 2012). As a result, they have a severe combined immunodeficiency, low levels or absence of type immunoglobulins IgA, IgM or IgG, reduction in size of lymphoid organs up to 10 times, absence of $\mathrm{T}$ and $\mathrm{B}$ lymphocytes and spleen cells fail produced them; thus rarely transplant reject. Her mutation occurred from the CB-17 strain (Bosma et al. 1983, Fulop \& Phillips 1990, Andrade et al. 2002). Selection of the most appropriate model will greatly facilitate future research and applications that require xenografting from bovine ovaries. Thus, this study was designed to evaluate the response of these two different strains of immunodeficient mice to bovine ovarian tissue that was xenografted underneath the renal capsule, both in the presence and absence of hormonal treatment.

\section{MATERIALS AND METHODS}

Ethics statement. The study was approved by the local ethics committee on animal experiments (No. 23091.002005/2013-23). The animals were maintained in accordance with Animal Care and Use Committee regulations.

Recipient animals. The recipients were female immunodeficient mice aged between 60 and 80 days from two different strains (BALB/c Nude/Nude, $n=9$; C57BL6 SCID, $n=12$ ) with proven cyclicity. Eight intact females from each strain were used to serve as the control group for vaginal washing and serum biochemistry. All animals were maintained in sterile cages under positive pressure at $22^{\circ} \mathrm{C}$ and $14: 10 \mathrm{~h}$ light/dark cycle, and fed ad libitum. Additionally, the animals were inspected daily for possible alterations in their behavior or health.

Selection of ovarian donors. Seven ovaries of crossbred heifers from the local slaughterhouse were used. These ovaries showed early follicular wave, presence of antral follicles, and absence of corpus luteum. The ovaries were collected immediately after slaughter and were washed briefly with saline solution $(0.9 \%)$, placed in sterile conical tubes $(50 \mathrm{~mL})$, labeled, and then transported in saline solution $(0.9 \%)$ with antibiotics $(100 \mathrm{~g} / \mathrm{mL}$ penicillin). The ovaries were then maintained at $37^{\circ} \mathrm{C}$ during transport to the laboratory.

Processing of donor ovaries. In the laboratory, the cortex of the ovaries was gently fragmented under a stereomicroscope into small pieces of approximately $1 \mathrm{~mm}^{3}$, placed in TALP/HEPES supplemented with $2 \%$ fetal bovine serum (Sigma - A9647) at the time of transplantation, which was always within $5 \mathrm{~h}$ of collection. Each ovary yielded 16 cortical pieces; one was separated for control histology and the remaining pieces were divided into five per recipient $(n=5)$ to be grafted without vascular anastomosis under the left renal capsule.

Anesthesia protocol, oophorectomy of recipients, and xenotransplantation. All mice were anesthetized with an intraperitoneal injection of 2,2,2-tribromoethanol (Avertin 2.5\%, Sigma-Aldrich, Sao Paulo, Brazil) at $20 \mathrm{~mL} / \mathrm{kg}$ (BALB/c Nude) and 18 $\mathrm{mL} / \mathrm{kg}$ (C57BL6 SCID). In order to prevent possible interference 
of the gonadal activity of the recipients following ovarian tissue transplantation, all BALB/c Nude and C57BL6 SCID mice were previously subjected to bilateral oophorectomy. Thereafter, the left kidney was located and externalized. The renal capsule was gently incised and five cortical pieces were grafted individually underneath the capsule. The animals were placed in sterile cages heated to $37^{\circ} \mathrm{C}$ until full recovery from the anesthesia and were sedated with ketoprofen (Laboratory Cristália, Brazil; $0.8 \mathrm{mg} / \mathrm{kg}$ ) intraperitoneally every $12 \mathrm{~h}$ for $2 \mathrm{~d}$.

Vaginal cytology. Five days after transplantation, vaginal washing was performed (every $12 \mathrm{~h}$ for $55 \mathrm{~d}$ ) to evaluate any putative estrous cycle. For this, the animals were contained, and a $20-\mu \mathrm{L}$ micropipette and saline solution $(0.9 \%)$ were used. Washes were evaluated by light microscopy (20x) and cells were evaluated in the absence of staining. The criteria for vaginal cytology were based on those reported by Cooper et al. (1993).

Hormonal treatment and graft recovery. Recipient females were divided into three groups as follows. Control (Group 1; $\mathrm{n}=$ 7), animals without hormone treatment; eCG (Novormon)-treated (Group 2; n=7), animals that received 10 IU e CG (Syntex Industry Biochemistry and Pharmaceuticals SA, Buenos Aires, Argentina); and FSH+LH (Group 3; n=7), animals that received $10 \mathrm{IU} \mathrm{FSH} \mathrm{+} \mathrm{LH}$ (Pluset, Laboratorios Calier SA, Barcelona, Spain). Sixty days after the surgery, the grafts were removed from the control group. eCG was administered in a single dose, whereas the FSH and LH combination was administered for 2 days every $12 \mathrm{~h}$. After $48 \mathrm{~h}$ of hormonal treatment, transplants were removed from the recipients of Group 2 and Group 3. All grafted animals were euthanized with an overdose of 2,2,2-tribromoethanol, followed by cervical dislocation. All the removed tissues were then processed for histology.

Histological processing and xenograft evaluation. Both control and grafted pieces were fixed in Carnoy's solution $(60 \%$ ethanol, $30 \%$ chloroform, $10 \%$ acetic acid) for $8 \mathrm{~h}$ and subsequently dehydrated, diaphonized, embedded in paraffin, and cut into $5 \mu \mathrm{m}$-thick serial sections. Every 20th section was mounted and stained with hematoxylin-eosin (HE) and Masson's trichrome (MT) (Molinaro et al. 2009).

The parameters used for ovarian tissue assessment were integrity of the parenchyma, quality of ovarian follicles, and vascularization. Additionally, in both control and the transplants, the follicles were classified according to the type and number of granulosa cell layers surrounding the oocyte following morphologic features (Rodgers \& Irving-Rodgers 2010). Preantral follicles (PF) were divided as follows: primordial, with an oocyte surrounded by a complete layer of squamous cells of pre-granulosa; primary, a single layer of cuboidal granulosa cells; secondary, with two or more layers of cubic granulosa cells. Antral follicles were classified as antral (with one or more small areas of follicular fluid) and preovulatory (those with a halo or layer of cumulus cells surrounding the oocyte). The atretic follicles followed the same classification of normal follicles on the type and number of layers, but differed based on the presence of nuclear pyknosis, cytoplasmic damage, disconnects between granulosa cells and the oocyte, as well as irregularities in the basement membrane.

Thermographic assessment. For thermographic evaluation, we used an infrared thermographic camera (FLIR b60, Flir Systems Brasil Comércio de Câmeras Infravermelhas Ltda, Sorocaba, Brazil). The images were taken $20 \mathrm{~cm}$ away from the studied tissues at three different times: T1, immediately after ovarian exposure at the slaughterhouse; T2, immediately after the xenografting procedure; $\mathrm{T} 3$, on the day of xenograft recovery when the animals were subjected to laparotomy for thermographic assessment. Image acquisition and analysis was performed using the Flir Software, and temperature gradients were then assessed.
Renal and hepatic biochemistry. The blood collection procedure was performed in the mornings in order to avoid variations in the biochemical parameters. Initially, the animal was anesthetized with intraperitoneal 2,2,2-tribromoethanol in the lateral lower right quadrant. After general anesthesia, the depth of which was assessed by the absence of foot reflex, $1 \mathrm{~mL}$ of blood was collected via cardiac puncture according to the procedure described by Hoff (2000). After this procedure, the animals were euthanized. The determination of death of the animals was performed by the lack of vital signs such as heart rate and breathing movements.

Blood from each animal was placed in pre-labeled 1.5- $\mathrm{mL} \mathrm{mi-}$ crofuge tubes, and centrifuged at $4000 \mathrm{rpm}$ for $10 \mathrm{~min}$ at room temperature to separate serum. All biochemical analyzes were validated and performed through spectrophotometry, using the semi-automatic biochemical analyzer Bioplus-200. Evaluation of renal function was determined by measuring blood urea nitrogen, creatinine, alanine aminotransferase (ALT), aspartate aminotransferase (AST), and alkaline phosphatase (ALP). Commercial kits were used for these measurements (Biotechnology Life, Belo Horizonte, Brazil).

Statistics. Data regarding kidney and ovarian tissue morphology were expressed descriptively. Mean duration of the phases of the estrous cycle, thermal evaluation, and biochemical data were compared by ANOVA followed by Tukey's test $(p<0.05)$. Percentage data was compared by chi-square $(\mathrm{p}<0.05)$. All comparisons were carried out according to the experimental groups with a probability level of 5\%. BioEstat 5.0 and Microsoft Office Excel 14.0 software were used for these calculations.

\section{RESULTS AND DISCUSSION}

The entire xenograft procedure consisted of bilateral oophorectomy, graft of fragments under the renal capsule, dieresis, and suture of the surgical wound. The average time for the procedure (18 $\mathrm{min}$ ) was not significantly different between the two strains. While the average time in the present study is lower than that observed by Liu et al. (2002), we did observe morphological differences between the two strains. The BALB/c Nude mice had a thick layer of peri-abdominal and visceral fat, probably to compensate for the loss of body temperature due to the lack of hair; in part, this hindered access to the organs of interest. In addition, in this strain, the kidneys were proportionately larger than those of the C57BL6 SCID mice. While this could be considered an advantage for transplantation studies, we also found that the renal capsule in BALB/c Nude was more fragile, making the grafting procedure more difficult in these mice. Thus, although anatomically smaller, C57BL6 SCID mice kidneys were superior to those of BALB/c Nude mice. All animals showed complete healing of the skin and muscles about 5 days after the surgery.

Another factor that might affect tissue revascularization and follicular activation after grafting is the choice of transplantation site. For this reason, we transplanted the ovarian fragments under the renal capsule in mice, because this area is extensively vascularized increasing the chances of survival of xenografted tissue (Kaneko, et al., 2013). Hernandez-Fonseca et al. (2004) demonstrated that bovine ovarian transplants under the renal capsule of male SCID mice produced significantly more follicles in growth than those transplanted subcutaneously. Yang et al. (2006) also observed that the recovery achieved in subcutaneous graft (56- 
$58 \%)$ was lower than that in the ovarian bursa (98-100\%) or under the kidney capsule (93-95\%), thus confirming the validity of our choice of the transplantation site. During the retrieval of the grafted tissues, we observed vascularization at the transplantation site, and $80 \%(\mathrm{n}=12)$ of the transplants in C57BL6 SCID and 77\% $(n=7)$ of the transplants in BALB/c Nude mice showed successful development.

The physiological status of the recipient may also influence the success of the grafting process and/or follicular survival. In some studies of ovarian transplantation, female mice are bilaterally oophorectomized, since this engenders high concentrations of gonadotropins, which are thought to be beneficial for graft survival and follicular development (Gosden et al. 1994, Candy et al. 1995, Wolvekamp et al. 2001). However, the hormonal response of the recipients may depend on the donor species and their age (Paris et al. 2004), in this last case it is widely known that oldest animals possess elevated concentrations of gonadotropins and reduced concentrations of steroid hormones in systemic circulation (Malhi et al. 2005). In the present study, we chose ovaries from heifers instead of cows, since we reasoned they would respond better to the transplant process and subsequent engraftment. Indeed, using this approach, over $75 \%$ of the fragments developed upon transplantation, which indicates a good rate of success.

Vaginal washing was performed in the control and grafted animals. Six of nine and 9/12 BALB/c Nude and C57BL6 SCID mice developed an estrous cycle, respectively. However, the cycles were longer in these animals than in the control group. Kaneko et al. (2003), Kaneko et al. (2006) used vaginal smears as an auxiliary method for the detection of cornified cells in the recipients, and this allowed them to determine the optimal time for hormonal stimulation and for the retrieval of oocytes that were suitably sized for in vitro fertilization. Considering proestrus as the first sign of the estrous cycle, the rate of return to cyclicity was $67 \%$ (BALB/c Nude) and 75\% (C57BL6 SCID); this occurred on average $9 \pm 3$ days in BALB/C Nude females and $19 \pm 9$ days in C57BL6 SCID females, although with a degree of irregularity. The grafted females had increased estrous cycle length. It is known that a female that has no contact with males tends to exhibit a prolonged anestrus (Santos 2002). In addition, a possible explanation for this increase is that animals require a longer time after ovarian xenografting for rehabilitation and revas-
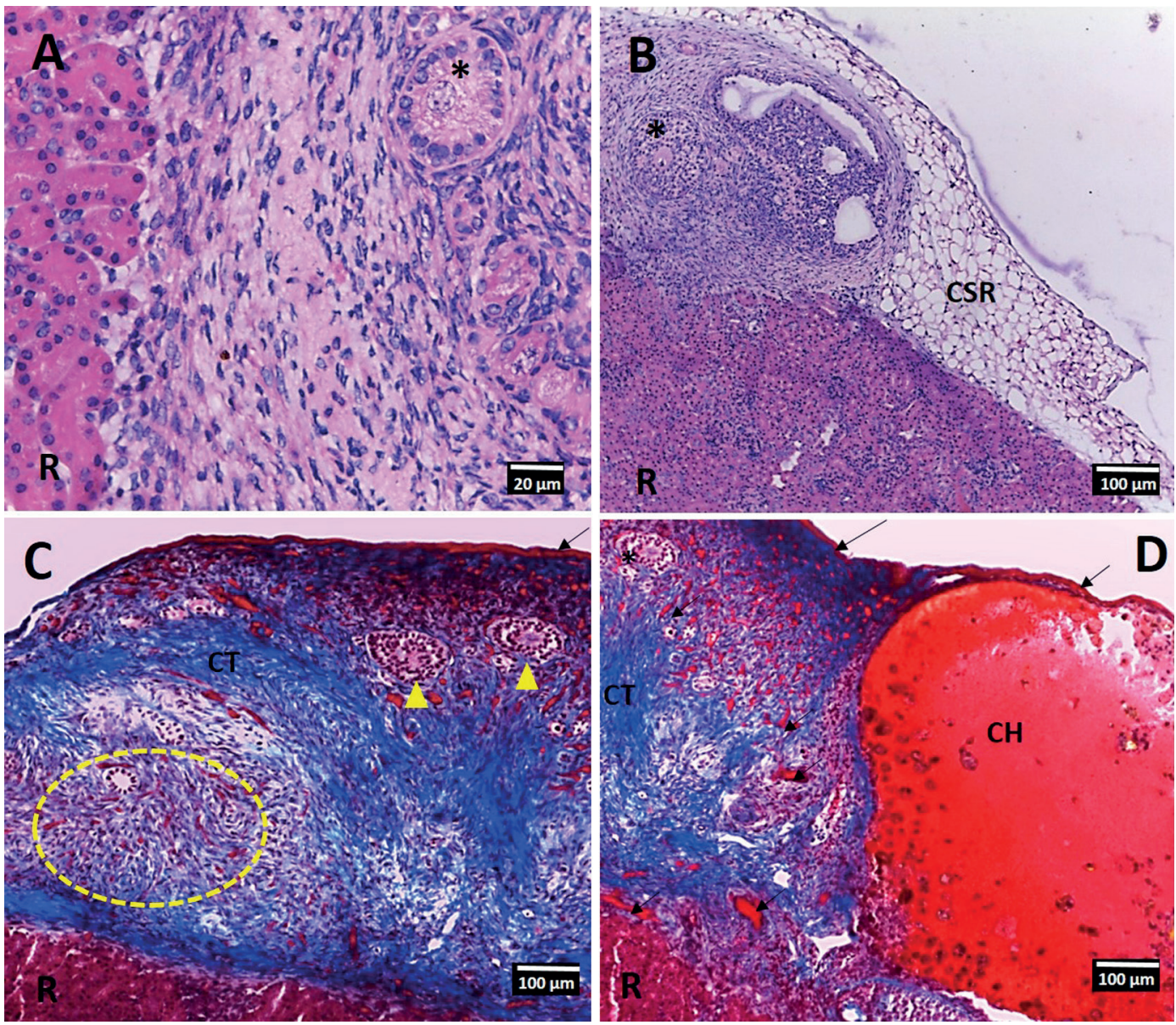

Fig.1. Ovarian cortex from heifer xenografted under the kidney capsule of BALB/c Nude mice (A,C) and C57Bl6 SCID (B,D). (A) Primary follicle $(*)$, note integration of ovarian cortical tissue and renal parenchyma of operated recipient (R). HE, 40x. (B) Secondary $(*)$ and tertiary follicles, renal parenchyma (R) of recipient Balb-c nude mouse, the region of the kidney capsule of the recipient (CSR) containing connective tissue. HE,10x. (C) Blood vessels observed in bovine ovarian tissue after xenotransplantation (dotted circle and arrow), secondary follicles (arrow head), connective tissue (CT), renal parenchyma of the recipient (R) MT 10x. (D) Hemorrhagic body $(\mathrm{CH})$, renal parenchyma of the recipient $(\mathrm{R})$, secondary follicles $(*)$; Note the vascularization surrounding $\mathrm{CH}$ (arrowheads) TM, 10x. 
cularization of the transplanted tissue. Thus, we think there is a temporal delay before signals from the hypothalamic-pituitary-gonadal axis reach the new grafted tissue.

Furthermore, a low number of preantral and tertiary follicles were observed in grafted cortical pieces. However, follicular activation was observed in xenografts from both strains. These findings are similar to those observed in other species including wallabies (Mattiske et al. 2002), cats (Bosch et al. 2004), and bovine fetuses (Bezerra 2010). The vascular supply of grafted tissues to the kidneys was morphologically similar to that found in the normal tissue of the ovarian donor, and neovascularization occurred in $77 \%$ and $80 \%$ of BALB/c Nude and C57BL6 SCID recipients, respectively (Fig.1). These observations coincided with cyclical return in the xenografts of these animals. Hypoxia and ischemic reperfusion plays an important role in the depletion of follicles from the first day after transplantation, and continues to do so for up to 1 week thereafter (Yang et al. 2006, Soleimani et al. 2011). During this phase, oxygen and nutrients diffuse into the surrounding tissue toward the graft, rescuing it from the ischemia and hypoxia that manifests in the presence of new (and immature) blood vessels; this process continues until revascularization is fully completed (Van Eyck et al. 2009).

Under physiological conditions, there is negative feedback between the pituitary and ovary; this regulates gonadotropin secretion and, thus, the development of the follicle. To stimulate the maturation of follicles in the growing xenografted tissue, recipients are often treated with exogenous gonadotropins. Here, we tested two hormonal protocols, and found that transplanted tissue developed in all females treated with FSH + LH and in $80 \%$ of those treated with eCG. Furthermore, the C57BL6 SCID animals showed

Table 1. Surface temperature of the entire ovary and transplanted ovarian tissue at different experimental times

\begin{tabular}{ccc}
\hline Time point & BALB/C/Nude & C57BL6 SCID \\
\hline T1 & $35.77 \pm 1.54^{\mathrm{aA}}$ & $35.97 \pm 1.50^{\mathrm{aA}}$ \\
T2 & $29.09 \pm 2.92^{\mathrm{bA}}$ & $27.95 \pm 2.04^{\mathrm{cA}}$ \\
T3 & $30.78 \pm 1.66^{\mathrm{bB}}$ & $32.79 \pm 1.58^{\mathrm{bA}}$
\end{tabular}

Lowercase letters indicate comparison within the strain. Capital letters indicate comparison between the models. T1, immediately after ovary exposure at the slaughterhouse; $\mathrm{T} 2$, immediately after the xenografting procedure; $\mathrm{T} 3$, on the day of xenograft recovery. hemorrhagic bodies in $48 \%$ ( $n=7$ ) of transplants; of these, $71 \%$ were induced by FSH+LH and 29\% by eCG. No hemorrhagic bodies were detected in BALB/c Nude females. With regard to follicular development, the FSH and LH hormone combination was more effective than treatment with eCG. In a murine model of human ovarian xenografts, Oktay et al. (1998) injected small doses of FSH in SCID mice for an extended period and observed the development of antral follicles. Similarly, Senbon et al. (2005) administered eCG $48 \mathrm{~h}$ prior to euthanizing a group of SCID mice xenografted with female secondary bovine follicles, and these follicles developed into oocytes of a suitable size for maturation. Several other studies have also confirmed that hormonal induction stimulates a more robust tissue response (Cleary et al. 2003, Kaneko et al. 2003, Bosch et al. 2004, Kaneko et al. 2006, Kaneko et al. 2013). However, it is still unclear whether the efficacy of the hormonal protocol is due to the effects on the donor tissue or on the hypothalamic-pituitary axis of recipient mice.

The hormonal status of the recipients can influence the result of the transplantation. Specifically, a higher concentration of gonadotropins from either endogenous or exogenous sources is desirable in order to obtain antral follicles capable of yielding oocytes that can be used for in vitro production. If the primary interest is in starting the growth of the primordial follicle, and thus maintaining the survival of a large number of follicles, then basal levels of FSH and LH are needed. Thus, more efficient hormonal treatments, tailored to the C57BL6 SCID strain, are required. This is because prevention of hemorrhagic body formation will facilitate the production of viable oocytes for use in other reproductive biotechnologies, and in particular for in vitro embryo production.

In this study, we used the infrared thermography technique because this facilitates the measurement of temperature distribution and the tracking of local temperature flux (Ring et al. 1985). Internal organs are not surrounded by a heat insulator, and their temperature is thus determined primarily by the flow of blood that perfuses the organ (Brioschi et al. 2000). When an artery serving an organ is supplied with blood, a "warm" anatomical pattern is clearly seen in whole-body thermal images (Suma et al. 2000). Although the donor ovarian tissue is maintained at the physiological temperature during collection, fragmentation,

Table 2. Plasma levels of renal and hepatic function of transplanted and intact immunodeficient mice models

\begin{tabular}{|c|c|c|c|c|c|c|}
\hline \multirow[t]{2}{*}{ Strain } & \multirow[t]{2}{*}{ Group } & \multicolumn{5}{|c|}{ Parameters } \\
\hline & & Urea (mg/dL) & ${ }^{*}$ Creatinine $(\mathrm{mg} / \mathrm{dL})$ & ${ }^{*}$ ALT $(\mathrm{u} / \mathrm{L})$ & ${ }^{*}$ AST $(\mathrm{u} / \mathrm{L})$ & ${ }^{*} \mathrm{ALP}(\mathrm{u} / \mathrm{L})$ \\
\hline \multirow[t]{4}{*}{ BALB/C/Nude } & Control & $76 \pm 4.43^{\mathrm{b}}$ & $0.30 \pm 0.08$ & $113 \pm 6.50^{\mathrm{a}}$ & $165 \pm 44.80^{\mathrm{a}}$ & $183 \pm 45.14^{\mathrm{a}}$ \\
\hline & Grafted control & $57 \pm 1.53^{\mathrm{a}}$ & $0.26 \pm 0.06^{\mathrm{a}}$ & $116=$ & $159 \pm 27.56^{\mathrm{a}}$ & $11.34^{\mathrm{a}}$ \\
\hline & $\mathrm{FSH}+\mathrm{LH}$ & $67 \pm 0.58^{a}$ & $0.30 \pm 0.00^{\mathrm{a}}$ & $110 \pm 27.15^{\mathrm{a}}$ & $166 \pm 62.45^{\mathrm{a}}$ & $189 \pm 41.79^{\mathrm{a}}$ \\
\hline & eCG & $62 \pm 2.52^{\mathrm{a}}$ & $0.30 \pm 0.10^{\mathrm{a}}$ & $117 \pm 44.82^{\mathrm{a}}$ & $157 \pm 55.12^{\mathrm{a}}$ & $185 \pm 29.69^{\mathrm{a}}$ \\
\hline \multirow[t]{4}{*}{ C57BL6 SCID } & Control & $63 \pm 5.12^{\mathrm{a}}$ & $0.35 \pm 0.06$ & $79 \pm 9.54^{\mathrm{a}}$ & $175 \pm 36.27^{\mathrm{a}}$ & $186 \pm 8.42^{\mathrm{a}}$ \\
\hline & Grafted Control & $59 \pm 3.813^{b}$ & $0.32 \pm 0.08^{\mathrm{a}}$ & $83 \pm 12.53^{\mathrm{a}}$ & $159 \pm 1.15^{\mathrm{a}}$ & $177 \pm 12.34^{\mathrm{a}}$ \\
\hline & $\mathrm{FSH}+\mathrm{LH}$ & $57 \pm 7.40^{\mathrm{b}}$ & $0.32 \pm 0.04^{\mathrm{a}}$ & $82 \pm 4.16^{a}$ & $166 \pm 29.67^{a}$ & $178 \pm 25.42^{\mathrm{a}}$ \\
\hline & eCG & $54 \pm 5.81^{b}$ & $0.32 \pm 0.11^{\mathrm{a}}$ & $79 \pm 10.00^{\mathrm{a}}$ & $160 \pm 27.68^{a}$ & $181 \pm 22.19^{\mathrm{a}}$ \\
\hline
\end{tabular}

Lowercase letters indicate comparison of lines with the same treatment. ${ }^{*}$ No significant difference was observed in either strain (where significance was defined as $\mathrm{p}<0.05$ ). ALT $=$ alanine aminotransferase, AST $=$ aspartate aminotransferase, ALP = alkaline phosphatase. 
and transplantation, we observed a significant difference in the degree of tissue ischemia between $\mathrm{T} 1$ and $\mathrm{T} 2$, and $\mathrm{T} 1$ and T3 in the BALB/c Nude and C57BL6 SCID procedures, respectively (Table 1). However, due to the reduced size of the fragment and the high level of reperfusion of the renal capsule, there was no statistical difference between $\mathrm{T} 2$ and T3 during BALB/c Nude procedures. There was a statistical difference between T2 and T3 during C57BL6 SCID procedures, suggesting that this strain, as expected, has advantages in thermoregulation due to the presence of hair. Our results indicate that infrared thermography cannot distinguish between the donor and recipient tissues, possibly due to the small size of the fragments we transplanted. However, this technique proved effective for monitoring the temperature of the recipient and transplant sites, and revealed that tissue engraftment was successful in animals of both strains, despite their significantly different body temperatures (Table 1).

Association of biochemical tests that report hepatic and renal function with behavioral data facilitates the evaluation of an animal's clinical condition, and can help determine whether xenotransplantation engendered pathology in the recipient. Our integration of these parameters revealed no significant difference between treatments for both strains studied, with the exception of urea (Table 2). Levels of this metabolite were lower in the BALB/c Nude mice than in control animals, but remained within the range of normal urea levels found in this strain.

As the serum creatinine excretion rate is relatively constant and is not influenced by protein metabolism or other external factors, creatinine concentration is an excellent parameter that can be used to evaluate renal function. Serum creatinine concentrations provide a more specific and sensitive alternative to plasma urea concentrations, particularly when the speed and level of glomerular filtration must be determined. However, creatinine concentrations very rarely exceed the reference limits until kidney function is compromised by $50-70 \%$. Therefore, a result in which creatinine levels are within the reference range does not necessarily imply normal renal function; thus, urea levels must also be evaluated in parallel (Emanuelli et al. 2008). We suggest that liver function should be monitored alongside the other parameters that we describe here, as the combination of results provides a strong indication of whether ovarian xenografts under the kidney capsule alter the physiology of the recipient.

\section{CONCLUSIONS}

Considering that ovarian transplants constitute an alternative source of donor genetic material, it is critical that methods for establishing xenotransplant viability, revascularization, and recovery of hormonal activity are optimized.

Infrared thermography does not enable the observer to individuate the donor tissue, likely due to the size of the fragments and the possible influence of heat emission from the kidneys.

The method was useful for observation the physiological status of the recipient and recipient tissue. Histology facilitated monitoring of blood reperfusion and follicular development after transplantation.
It was also an effective method for assessing the ovarian xenografts via vaginal cytology, as it could identify the return of cyclicity in the animals, and provide an index of recipient kidney and liver functions.

Our data demonstrate that transplantation under the kidney capsule provides an optimal physiological niche for ovarian xenografts, with relatively little negative impact on the recipient.

Although the C57BL6 SCID strain proved to be the best host for ovarian xenografts, supplementation with hormones was still required in order to provide oocytes that are suitable for in vitro production.

Acknowledgements.- We thank the Coordination of Superior Level Staff Improvement (CAPES-Brazil) for scholarships granted to postgraduate students from the Program in Animal Science - UFERSA, and the National Council of Technological and Scientific Development (CNPq-Brazil) for supporting part of this project $(483890 / 2012)$. We would like to thank Editage (www.editage.com.br) for English language editing.

Conflict of interest statement.- The authors have no competing interests.

\section{REFERENCES}

Andrade A., Pinto S.C. \& De Oliveira R.S. 2002. Animais de laboratório: criação e experimentação. SciELO, Editora Fiocruz. 388p.

Aubard Y. 2003. Ovarian tissue xenografting. Eur. J. Obstet. Gyn. R. B. 108:14-18.

Bedaiwy M.A., Shahin A.Y. \& Falcone T. 2008. Reproductive organ transplantation: advances and controversies. Fertil. Steril. 90:2031-2055.

Bezerra M.B. 2010. Bovine preantral follicles in vitro culture and xenotransplantation. 63p. Thesis (Doctorate of Veterinary Medicine), Faculty of Agriculture and Veterinary Sciences, São Paulo State University, Jaboticabal, São Paulo, Brazil.

Bosch P., Hernandez-Fonseca H.J., Miller D.M., Wininger J.D., Massey J.B., Lamb S.V. \& Brackett B.G. 2004. Development of antral follicles in cryopreserved cat ovarian tissue transplanted to immunodeficient mice. Theriogenology 61:581-594.

Bosma G.C., Custer R.P. \& Bosma M.J. 1983. A severe combined immunodeficiency mutation in the mouse. Nature.

Brioschi M.L., Cimbalista J.R.M., Nakagawa C.R., Von Bahten L.C. \& Brofman P.S. 2000. Intraoperative assessment of cardiac revascularization by thermal coronary angiography: preliminary experimental study. Arq. Méd. PUCPR, Curitiba, 2:33.

Candy C.J., Wood M.J. \& Whittingham D.G. 1995. Ovary and ovulation: Follicular development in cryopreserved marmoset ovarian tissue after transplantation. Hum. Reprod. 10:2334-2338.

Cleary M., Paris M.C.J., Shaw J., Jenkin G. \& Trounson A. 2003. Effect of oophorectomy and graft position on cryopreserved common wombat (Vombatus ursinus) ovarian tissue following xenografting to nude mice. Reprod. Fertil. Dev. 15:333-342.

Cooper R.I., Goldman J.M. \& Vandenbergh J.G. 1993. Monitoring of the estrus cycle in the laboratory rodent by vaginal lavage, p.45-55. In: Heindel J.J. \& Chapin R.E. (Eds), Female Reproductive Toxicology, Methods in Toxicology. 3rd ed. Academic Press, San Diego.

Emanuelli M.P., Dos Anjos Lopes S.T., Maciel R.M., Garmatz B.C. \& Tavares M.D.O. 2008. Concentração Sérica de Fosfatase Alcalina, Gama-glutamil transferase, uréia e creatinina em coelhos (Oryctolagus cuniculus). Ciênc. Anim. Bras. 9:251-255.

Fulop G.M. \& Phillips R. A. 1990. The scid mutation in mice causes a general defect in DNA repair. Nature 347:479-482.

Gosden R.G., Boulton M.I., Grant K. \& Webb R. 1994. Follicular development from ovarian xenografts in SCID mice. Reproduction 101:619-623.

Hernandez-Fonseca H., Bosch P., Sirisathien S., Wininger J.D., Massey J.B. 
\& Brackett B.G. 2004. Effect of site of transplantation on follicular development of human ovarian tissue transplanted into intact or castrated immunodeficient mice. Fertil. Steril. 81:888-892.

Hoff J. 2000. Methods of blood collection in the mouse. Lab. Anim. 29:47-53.

Johnson M. 2012. Laboratory Mice and Rats. Labome <http://www.labome.com/method/Laboratory-Mice-and-Rats.html> Access on May 23, 2016.

Kaneko H., Kikuchi K., Noguchi J., Hosoe M. \& Akita T. 2003. Maturation and fertilization of porcine oocytes from primordial follicles by a combination of xenografting and in vitro culture. Biol. Reprod. 69:1488-1493.

Kaneko H., Kikuchi K., Noguchi J., Ozawa M., Ohnuma K., Maedomari N. \& Kashiwazaki N. 2006. Effects of gonadotropin treatments on meiotic and developmental competence of oocytes in porcine primordial follicles following xenografting to nude mice. Reproduction 131:279-288.

Kaneko H., Nakai M., Tanihara F., Noguchi J. \& Kikuchi K. 2013. Improved developmental ability of porcine oocytes grown in nude mice after fusion with cytoplasmic fragments prepared by centrifugation: A model for utilization of primordial oocytes. Theriogenology 80:887-892.

Kikuchi K., Nakai M., Kashiwazaki N. \& Kaneko H. 2011. Xenografting of gonadal tissues into mice as a possible method for conservation and utilization of porcine genetic resources. Animal Science Journal. 82:495503.

Liu J., Van Der Elst J., Van Den Broecke R. \& Dhont M. 2002. Early massive follicle loss and apoptosis in heterotopically grafted newborn mouse ovaries. Hum. Reprod. 17:605-611.

Malhi P. S., Adams G. P. \& Singh J. 2005. Bovine model for the study of reproductive aging in women: follicular, luteal, and endocrine characteristics. Biology of Reproduction 73:45-53.

Mattiske D., Shaw G. \& Shaw J.M. 2002. Influence of donor age on development of gonadal tissue from pouch young of the tammar wallaby, Macropus eugenii, after cryopreservation and xenografting into mice. Reproduction 123:143-153.

Molinaro E.M., Caputo L.F.G. \& Amendoeira M.R.R. 2009. Conceitos e Métodos para a Formação de Profissionais em Laboratórios de Saúde. Vol.4. Universidade Federal de São João Del-Rei, Minas Gerais, p.1-496.

Oktay K., Newton H., Mullan J. \& Gosden R.G. 1998. Development of human primordial follicles to antral stages in SCID/hpg mice stimulated with follicle stimulating hormone. Hum. Reprod. 13:1133-1138.

Paris M.C., Snow M., Cox S.L. \& Shaw J.M. 2004. Xenotransplantation: a tool for reproductive biology and animal conservation? Theriogenology 61:277-291.

Ricarte A.R.F., Façanha D.A.E. \& Costa L.L.M. 2014. Possibilities of the use of infrared thermography in reproductive diagnostics in goats. Acta Vet. Brasilica 8:380-384.

Ring E.F.J., Watson C. \& Barker J. 1985. Infrared thermography and thermal clearance of the skin. Applied Thermology, VCH Publ., Weinheim, Germany, p.133-141.

Rodgers R.J. \& Irving-Rodgers H.F. 2010. Morphological classification of bovine ovarian follicles. Reproduction 139:309-318.
Samaniego M., Becker B.N. \& Djamali A. 2006. Drug insight: maintenance immunosuppression in kidney transplant recipients. Nat. Rev. Nephrol. 2:688-699.

Santos B.F. 2002. Criação e manejo de camundongos, p.115-118. In: Andrade A., Pinto S.C. \& Oliveira R.S. (Eds), Animais de Laboratório: criação e experimentação. Fiocruz, Rio de Janeiro.

Senbon S., Ishii K., Fukumi Y. \& Miyano T. 2005. Fertilization and development of bovine oocytes grown in female SCID mice. Zygote 13:309-315.

Shultz L.D., Schweitzer P.A., Christianson S.W., Gott B., Schweitzer I.B., Tennent B., Mckenna S., Mobrateen L., Rajan T.V. \& Greiner D.L. 1995. Multiple defects in innate and adaptive immunologic function in NOD/ LtSz-scid mice. J. Immunol. 154:180-191.

Silber S.J. 2012. Ovary cryopreservation and transplantation for fertility preservation. Mol. Hum. Reprod. 18:59-67.

Silber S., Kagawa N., Kuwayama M. \& Gosden R. 2010. Duration of fertility after fresh and frozen ovary transplantation. Fertil. Steril. 94:21912196.

Soleimani R., Heytens E. \& Oktay K. 2011. Enhancement of neoangiogenesis and follicle survival by sphingosine-1-phosphate in human ovarian tissue xenotransplants. PLoS One e19475, 6:1-8.

Sonmezer M. \& Oktay K. 2010. Orthotopic and heterotopic ovarian tissue transplantation. Best Pract. Res. Cl. Ob. 24:113-126.

Stewart M., Webster J.R., Schaefer A.L., Cook N.J. \& Scott S.L. 2005. Infrared thermography as a non-invasive tool to study animal welfare. Anim. Welf. 14:319-325.

Suma H., Isomura T., Horii T. \& Sato T. 2000. Intraoperative coronary artery imaging with infrared camera in off-pump CABG. Ann. Thorac. Surg. 70:1741-1742.

Van Eyck A., Jordan B.F., Gallez B., Heilier J.F., Van Langendonckt A. \& Donnez J. 2009. Electron paramagnetic resonance as a tool to evaluate human ovarian tissue reoxygenation after xenografting. Fertil. Steril. 92: 374-381.

Von Schonfeldt V., Chandolia R., Ochsenkuhn R., Nieschlag E., Kiesel L. \& Sonntag B. 2012. FSH prevents depletion of the resting follicle pool by promoting follicular number and morphology in fresh and cryopreserved primate ovarian tissues following xenografting. Reprod. Biol. Endocrinol. 10:98-98.

Wiedemann C., Hribal R., Ringleb J., Bertelsen M.F., Rasmusen K., Andersen C.Y. \& Jewgenow K. 2012. Preservation of primordial follicles from lions by slow freezing and xenotransplantation of ovarian cortex into an immunodeficient mouse. Reprod. Domest. Anim. 47:300-304.

Wolvekamp M.C.J., Cleary M.L., Cox S.L., Shaw J.M., Jenkin G. \& Trounson A.O. 2001. Follicular development in cryopreserved common wombat ovarian tissue xenografted to nude rats. Anim. Reprod. Sci. 65:135147.

Yang H.Y., Cox S.L., Jenkin G., Findlay J., Trounson A. \& Shaw J. 2006. Graft site and gonadotropin stimulation influences the number and quality of oocytes from murine ovarian tissue grafts. Reproduction 131:851859. 